\title{
Phonological Interference and Morphology of BMT in Student Narrative Essays, Indonesia
}

\author{
Irmayani Putri ${ }^{1}$, Syahnan Daulay ${ }^{2}$, Malan Lubis ${ }^{2}$ \\ ${ }^{1}$ Master Student in Indonesia Language, Postgraduate Program, State University of Medan (Unimed), Indonesia \\ ${ }^{2}$ State University of Medan (Unimed), Indonesia
}

\begin{abstract}
This Study dealt with Morphology of BMT in Student Narrative Essays, Indonesia In Tamiang Dialect. The influence of the downstream dialect language of Tamiang cannot be ignored by the people of Tamiang Hilir. The Lower dialect Tamiang language used since childhood in the home, family environment, and the community has been so pervasive to the users of the local language. This fact shows that the people of Tamiang Hilir often use Indonesian in a formal environment or only certain circles. The method used in this research is descriptive qualitative method. Qualitative research generally tries to form or construct theory through collected data. In the description, it is presented in a systematic, factual, and accurate manner regarding the data and characteristics of the phenomena studied. The result shows that There are phonological equations, morphology in Malay and Indonesian. Because, Indonesian root groups adopted the Malay language as the basis for use. So that many lexical meanings are homonym, homograph and hyponym in Malay that are similar to Indonesian and other regional languages.
\end{abstract}

Keywords : Tamiang Hillir; Morphology; Narrative Essay; Phonology

\section{Introduction}

The Tamiang community has its own accent or dialect, most of the Tamiang languages in writing are almost the same as Indonesian. In pronunciation and writing very different spoken. The example of the word "Orang" is still written in the Tamiang language as "people" but the pronunciation is different because the word " $\mathrm{R}$ " is thickened at the time of reading.

Table 1. Example of Lower Dialect of Tamiang Interference against Indonesian writing

\begin{tabular}{|l|l|l|}
\hline No. & Tamiang Language of Hilir & Bahasa Indonesia \\
\hline 1 & Nini & Nenek \\
\hline 2 & Simbah & Siram \\
\hline 3 & Nyabak & Menangis \\
\hline 4 & Mbaco & Membaca \\
\hline 5 & Nanak & Memasak \\
\hline 6 & Melainke & Melainkan \\
\hline 7 & Sehinggo & Sehingga \\
\hline
\end{tabular}

The influence of the downstream dialect language of Tamiang cannot be ignored by the people of Tamiang Hilir. The Lower dialect Tamiang language used since childhood in the home, family environment, and the community has been so pervasive to the users of the local language. This fact shows that the people of Tamiang Hilir often use Indonesian in a formal environment or only certain circles. When communicating with the surrounding community or ethnic groups, the speakers of the mother are more likely to use Indonesian, but the Indonesian language that they use is still influenced by the structure of their mother tongue, so there are transfers of elements of regional language into the Indonesian language they use. 
Like the word "baju engko" which should be in Indonesian "baju engko" which should be "your shirt".

Related to written language, the Tamiang community is no different from other ethnic communities that inhabit Aceh Province, which uses Arabic-Malay letters. This writing is known after Islam came to Aceh. However, this writing gradually became obsolete, not only in Tamiang but also throughout the Aceh region. This is caused by the dominant use of Latin letters, both in teaching in schools and in various writings in government and society One of the regional languages that experience language contact is the Tamiang language. Contacting the language in Tamiang with Indonesian is due to bilingualism or bilingual mastery. Tamiang is a mother tongue whose roots are the same as Indonesian. Therefore, there is an assumption that Tamiang language is not much different from Indonesian. The events of mixing two languages or more in this speech are in the realm of interference. Because interference occurs more freely in two languages that are considered to have both structural and lexical closeness, the Tamiang language interference with the communication of students who are in Indonesian needs to be proven.

In Aceh, especially in the Tamiang area, many bilingual speakers are found. Bilingual speakers usually use local language to be more familiar and familial in informal situations, and to use Indonesian when in official situations. The reluctance to use Indonesian is increasingly bad for Indonesian language development as well as writing. Especially in terms of writing which is one of the language skills. Many people use local languages verbally, moreover the Tamiang language is the same language as the Indonesian language in writing, but reading the word is slightly different, but only a few languages are the same. Therefore the author examines the interference that occurs in writing Tamiang language in Indonesian in the student writing range. Interference is a phenomenon of the deviation of its rules. Language influences that occur due to someone mastering two or more languages. Suwito (1983: 54) argues that interference is a deviation because the elements absorbed by a language already have equivalents in absorbent languages. So, the manifestation of the cause of interference is the ability of speakers to use certain languages.

\section{Literature review}

\subsection{Language Contact}

Language contact is an event that has happened for a long time and continues to this day and in the future. Language contact is the influence of one language on another language both directly and indirectly, giving rise to language changes possessed by the ecology of the language. Then bilingualism occurs as a result of language contact. Language contact not only takes place within an individual, but in a social situation. Therefore, language contact is often also considered as part of wider contact, namely cultural contact. Language contact does not involve individuals but people who learn a second language, but also other people. Other language elements which previously only influenced the bilingualism then spread more widely so that the influence gained mutual reinforcement. At this level it can be said that language contact has occurred.

Weinreich (1968: 1) suggested contact language as an event: "two languages will be said in contact if they are used alternatively by the same person. The language used by individuals is thus a focus of contact. The alternately using two languages will be called bilingualism and the persons involved, bilinguals ".Unlike the case with Weinreich, Mackey explicitly distinguishes language contacts from bilingualism, language contact is the 
influence of a language on other languages in langue, and is a permanent possession, not only by the bilingual but also the ekabahasawa. Opinions that are similarly expressed by Rusyana (1988: 4) also distinguish between malpractice and language contact. In Rusyanan's view, language contact is the influence of one language on another language which results in changes in the language system and becomes the permanent possession of the language speaker both directly and indirectly. In addition, Suwito (1983: 39) says language contact occurs in speakers individually, while individuals in the place of language contact are called bilingual.

According to Mackey (in Suwito, 1985: 39) language contact is the influence of one language on another language both directly and indirectly, giving rise to language changes possessed by the Eucharist. Language contact tends to language symptoms, whereas bilingualism is more likely to be a speech symptom (parole). Language is essentially the source of parole, so language contact must be in bilingualism. Then bilingualism occurs as a result of language contact.

\subsection{Divinity}

The term bilingualism or bilingualism can be used for individuals (individual bilingualism) and can also be used for the community (Societal bilingualism). If observed, bilingualism in a society can be seen based on two extreme theoretical circumstances. The first is a situation where all days in work and social interaction. The second extreme is if there are two languages in the society, but everyone knows only one language and thus the society consists of two monolingual and separate communication networks.

The community is not only able to master one language, because with the strong flow of social cultural interaction with other nations it is possible for cultural assimilation among many different cultural backgrounds, thus there are many languages circulating in the community. This then creates a bilingual (multilingual) and multilingual situation (various languages). The ability to use two languages or more by someone is called the bilingual or bilingualism. The meaning of bilingualism is the event of someone's bilingual mastery. A person who has the ability to use two languages alternately is called a bilingual.

According to Weinreich (in the book Aslinda and Leni, 2007: 23), bilingualism is the practive of alternately using the language (the habit of using two languages or more alternately). Whereas according to Blommfield (in the book Aslinda and Leni, 2007: 23), it reveals that bilingualism is native to like control of two languages. This opinion is based on the understanding of the language given, namely a code system that has special characteristics. Knowing two languages means being able to use two code systems properly. Divinity as a manifestation of language contact is a term whose meaning is relative or relati, (Suwito, 1982: 40, in the book Aslinda and Leni, 2007: 23).

\subsection{Language Contact}

Language contact events occur in individual language speakers. If two languages or more are used interchangeably by a speaker it can be said that these languages are in contact with each other. An individual where the language contact occurs is dual language, while the event of using two languages or more alternately by a speaker is called bilingualism. Mackey in Suwito (1983: 39) describes the language contact as follows,

... the understanding of language contact as the influence of one language on another language both directly and indirectly or indirectly, giving rise to changes in language 
possessed by the ecology of the language. Whereas bilingualism is defined as the use of two or more languages by a speaker.

In the opinion above, it is emphasized that language contact tends to language symptoms (langue) while bilingualism is more likely to be a speech symptom (parole). However, because langue is essentially a source of parole, language contact should be visible in the wickedness. In other words, bilingualism occurs as a result of language contact.

Monolingual is the ability to use only one language (which is usually found in many parts of the western world). The term bilingualism in Indonesian is also called bilingualism. The term bilingualism is easy to understand because it deals with the use of two languages or two language codes (Chaer, 2010: 84).

\subsection{Interference}

The term interference was first used by Weinreich 1953 in the book Chaer (2004: 120) to mention the change in the system of a language in connection with the presence of the language with other language elements performed by speakers who are bilingual. Interference events occur in bilingual speech as a result of its ability in other languages. According to Chaer (2012: 66) interference is carried away by the entry of other language elements into the language that is used, so that there appears to be a deviation from the language being used. Interference can occur at all levels of language.

Ueyama in A-Roud (2015: 82) states that interference indicates that there is a first language (L1) background that is involved in learning a second language (L2). This background can be illustrated by the characteristics of L1 especially the structures which influence the L2. For instances, when adults, who typically have accents, learn to pronounce or speak L2, their accent will be sound as foreign accented.

Interference in English is called interference, which means interference that is used in sociolinguistics. Interference is a language phenomenon that arises in a bilingual society caused by language contact so that language norms are deviated. In language contact results in the influence of each other's elements of language.

Jendra (2012: 94) The interference is identified when the language is produced in a second or foreign language (L2), which means that interference is identified when speech is produced in a second or foreign language (B2) seems influenced by the learner's first language (B1).

Interference in the journal Muntiqoh (2016: 89), his book entitled "Language Two" Dulay, H, et al. (1982: 98) say that interference refers to two very different language phenomena. The first is psychological and the second is sociolinguistic. Psychologically the term interference refers to the influence of old habits when new habits are being studied. In sociolinguistic, the term interference refers to the interaction of languages, such as 'linguistic borrowing' and 'code switching' which occur when two language communities are related.

Interference in general can be interpreted as mixing in the field of language. Mixing is meant by mixing two languages or interplay between two languages. In the event of interference, other language elements are used in using a language, which is considered an error because it deviates from the rules or rules of the language used. And the ability of bilingual speakers and multilingual speakers to use certain languages so that other languages are affected is the cause of interference. The ability of each speaker to speak the first language in the second language varies. For example, in using Indonesian and English. If someone is said to be multilingual or know two languages either well or perfectly. He will 
often include the languages he understands in his communication or is often said to be code switching and code mixing.

The definition of interference in Sainil Amral's research (2011: 58) is based on Hartman Jan and Stork's opinion, interference which is a mistake caused by a tendency to familiarize the pronunciation or utterance of a language to other languages including the pronunciation of sounds, grammar and vocabulary. Thus, Hartman and Stork show that actual interference is an unintentional influence, namely a mistake that continues so that it can be a mistake in language speech acts.

Interference occurs in bilingual speech when there is language contact and bilingualism. Interference is also characterized as a manifestation of the use of certain elements in a language into other languages, can be phonology, morphology, morphology, lexical, and syntax, both verbally and in writing. The interference intended in this paper is the phenomenon of speech.

\subsection{Variety of Writing Languages}

Written language according to Abdul Chear (2012: 83-84) suggests that, written language is not an oral language written as it happens with if we record the spoken language into the tape. The written language has been made by people with consideration and thought, because otherwise be careful, without consideration and thought, the opportunity for mistakes and misunderstandings in written language is very large. If an accident occurs, then the error cannot be corrected directly.

Kosasih (2011: 3) the variety of languages according to the ingredients is commonly divided into various oral and various types of writing. The two languages have the following differences:

1) Sentences in a variety of spoken languages are generally short, intermittent, and the functions of the sentence are broken. A variety of spoken languages tend to bring up vocabulary conversations such as "but, what, this, anyway, oh, yes, how come" and so on.

2) The use of written language needs to be more careful. This is because the parties invited to communicate are not face to face. To ensure the effective delivery of messages, grammatical functions, such as subject, predicate, and object and the relationship between functions must be complete and real. To express an agreement, for example, our variety of writings must express it in full words, "I totally agree with your opinion. I am happy to hear that invitation" and other similar expressions.

Differences in situations and conditions of use affect the emergence of diversity in Indonesian. Based on these factors, Indonesian is known for its official writing and unofficial writing variety. A variety of official written languages are used in formal situations, such as speeches in state, writing scientific papers, and the like. Unofficial languages are used in casual situations, which are informal, such as when writing personal letters, diaries and essays.

Kosasih (2011: 4) Official whether or not a language is used can be known through standard language rules or guidelines set by the government or by linguists. Indonesia, official language guidelines can refer to:

(1) EYD Regulations

(2) Guidelines for term formation

(3) Large Indonesian Dictionary

(4) The standard grammar of the Indonesian language 
Furthermore Widjono (2012: 32-34) The types of languages are divided into 3 namely based on media, based on time, and communication messages. The variety of Indonesian languages based on the media is divided into two, namely the variety of media languages (oral) and variety of writing. Widjono (2012: 33) Variety of written languages is the language produced by using writing with letters as the basic element. In a variety of writing, we deal with the procedures for writing and vocabulary.

\section{Research Methods}

The method used in this research is descriptive qualitative method. Qualitative research generally tries to form or construct theory through collected data. In the description, it is presented in a systematic, factual, and accurate manner regarding the data and characteristics of the phenomena studied.

Bogdan and Taylor in Moleong (2002: 60) define qualitative research as research that produces descriptive data in the form of written words or writings from people and observable behavior. The method used in this research is the descriptive method, namely a method that attempts to describe a phenomenon or phenomenon that occurs in a real state. Descriptive methods are used to solve problems and answer the problems achieved in the current situation which are carried out by taking steps to collect, classify and analyze or collect data, make conclusions and reports with the aim of making descriptive descriptions of the situation."

This research was carried out in SD Negeri Raja Elementary School and Grade V Lubuk Batil Elementary School in the Bendahara District of Aceh Tamiang Regency. This research took place in July 2018. The data of this study are words in sentences containing Lexical interference in the Tamiang language in Indonesian $\mathrm{V}$ grade students. This research data comes from essays in the form of narrative essays of students with the theme of $\mathrm{V}$-grade elementary school holidays in the Bendahara District of Aceh Tamiang Regency. The results of student interference are obtained from the results of written observations, in addition to written data, which are needed are questionnaires filled out by students and interviews aimed at teachers who teach Indonesian language lessons at the school.

The data source in this study is the fifth grade elementary school students of the Bendahara District of Aceh Tamiang Regency. The choice of place of research is because in the school the majority of the Tamiang tribes are in accordance with the objectives of the research to be conducted.

Gay (in Umar 2005: 79) suggests that if the research design used is a descriptive method, the minimum size of the sample can be received by $10 \%$ of the pollution. For a relatively large population at least $20 \%$ of the population. In addition, Musfiqon (2012: 91) also stated:

If there are limitations, either funds, time or means of research involving large populations are obtained by taking samples. The normal used is if the population exceeds 100 people, sampling can be done. Sampling is adjusted to the size of the population, which ranges from 20-30 percent of the total population. But if the population of less than 100 people should be studied all of them.

Given the study population is less than 100 people; the withdrawal of this study sample (determining the amount of data to be studied) is $10 \%$ of the population. So, the number of samples of this study is 3 narrative essays produced by these students. 
Determination of the sample in this study using purpose sampling technique. Mahsun (2005: 211) states that this technique is used with consideration of only lexical interfering essays, the Tamiang language in the Indonesian narrative essay taken into the research sample. Determination of the number of samples (sample size) uses systematic sampling, namely the way that is done by determining the percentage of the number of samples to be taken.

\section{Discussion}

\subsection{Phonology}

Phonological interference in the narrative essay of fifth grade elementary school students in the Bendahara district of Aceh Tamiang Regency that occurs in his essay are morpheme or word changes based on phonetically distinguishing features. Changes usually occur like phoneme removal at the beginning, middle, and end in a few words. Through the process of phoneme replacement, phoneme impingement, syllable replacement, and removal of one phoneme

Phoneme replacement is a process of alternating articulated phonemes, phonemes which have the same meaning made unequal in their pronunciation sounds. In this context in writing, these changes usually occur in the initial, middle and end phonemes. Usually phonemes in BI are replaced with BMT phonemes which can be seen in the following table.

Table 2. Substitution of BI Vocal Phonetic Sound to BMT

\begin{tabular}{|l|l|l|l|}
\hline No & Phoneme & BI words & BMT Words \\
\hline 1 & / é /-/a/-/i/ & Sungai & Sungé \\
\hline 2 & /a/-/o/ & Baca & Baco \\
\hline 3 & $/ \mathrm{u} /-/ \mathrm{o} /$ & Untuk & Untok \\
\hline 4 & $/ \mathrm{a} /-/ \mathrm{e} /$ & Kuburnya & Kuburnye \\
\hline 5 & $/ \mathrm{i} /-/ \mathrm{e} /$ & Fasih & Faseh \\
\hline 6 & $/ \mathrm{i} /-/ \mathrm{e} /$ & Balik & Balek \\
\hline 7 & /i/-/e/ & Kutip & Kutep \\
\hline
\end{tabular}

Phonological interference through the process of dissimilation, namely there is a sound change from two sounds that are the same or similar to sounds that are not the same or different (Kuwing, 2007: 34 in the journal Mabasan, Vol. 11, No. 1) on the different sounds, namely at vowel / é / - / a / - / /, / a / - / o /, / u / - / /, / a / - / e /, / / / / e /, / i / - / e / and / i / - / e /. the substitution of the consonant phoneme occurs with the passing of the consonant and vowel phonemes occurring on phone $/ \mathrm{h} /$, and $/ \mathrm{t} /, / \mathrm{k} /$ sound, which is called syllable sound according to Putradi, 100: 2006 (Vol. 3, No. 2 in arbitrary journals published October 2016 ) syllable syllables are the smallest rhythmic units in a stream of speech. One syllable usually involves one vowel sound or one vowel and one consonant or more. See table 4.11 below.

Phonological interference through the process of dissimilation, namely there is a sound change from two sounds that are the same or similar to sounds that are not the same or different (Kuwing, 2007: 34 in the journal Mabasan, Vol. 11, No. 1) on the different sounds, namely at vowel / é / - / a / - / i /, / a / - / o /, / u / - / o /, / a / - / e /, / i / / e /, / i / - / e / and / i / - / e /. the substitution of the consonant phoneme occurs with the passing of the consonant 
and vowel phonemes occurring on phon / h /, and / t /, / k / sound, which is called syllable sound according to Putradi, 100: 2006 (Vol. 3, No. 2 in arbitrary journals published October 2016 ) syllable syllables are the smallest rhythmic units in a stream of speech. One syllable usually involves one vowel sound or one vowel and one consonant or more. See the following table.

Table 3. Substitution of consonant and vowel phonemes

\begin{tabular}{|l|l|l|l|}
\hline No & Phoneme & BI Words & BMT Words \\
\hline 1 & $/ \mathrm{h} /-\mathrm{i} /$ & H-abis-i-tu & Abistu \\
\hline
\end{tabular}

Table 4. Substitution of Tamiang Malay Language Consonant Phonemes

\begin{tabular}{|l|l|l|}
\hline No & Phoneme & BMT Words \\
\hline 1 & $/ \mathrm{t} /-/ \mathrm{k} /$ & $/$ Duit/-/duik/ \\
\hline 2 & $/ \mathrm{k} /$ & $/$ Akak/-/kakak/ \\
\hline
\end{tabular}

\subsection{Morphological Interference}

Interference in the form of words or morphology that is there is the formation of words with affixes. The affixes of a language are used to form words in other languages giving rise to new meanings. Affixation can occur in the front like affixation, including the words Mengaji, Tertido. The recitation is the addition of my prefix in front of the basic word morphological review in the word change when I get my prefix in front of the basic word. This happens because affixation with prefixes can be in the form of phoneme sequencing, phoneme addition, and phoneme leaching. However, the word kaji fonem experiences pulverization or nasal, because the basic form of the study is a consonant form.

The highest affix to the word tido in BMT interference which means sleeping on BI is the addition of the ter prefix in front of the verb, the addition of the derivative ter prefix has the grammatical meaning that describes the state. In verbs with derivative ter-prefixes have grammatical meanings describing a situation. Sleep is a verb that describes the situation that is done, if it is added with a prefix it will be a sleepy word the meaning of the word changes to an explanation of the state of the verb. Ter is also an affix which explains accident when a certain grammatical arrangement of meanings, on the supine word in the narrative essay of the supine student becomes a form of accidental action or a description of the condition of the derivative in the verb depending on the context of the sentence in syntax. example: the item was stepped on by me earlier.

The formation of basic words in the morphological process of the night prefix into overnight is a form on the basic word adjective giving the same grammatical meaning to the base word with the noun following it. The formation of the word overnight addresses the description category in grammatical meaning. Example. (Last night / one night)

(Overnight)

(Overnight / sleep / sleep one night)

Phoneme sequencing refers to crooked words that do not change or are erased and added to phonetic pronunciation. This happens if the basic form begins with the consonant / $r, l, w, y, m, n, n g$, and $n y /$. The morphemic form will be nasal if the basic word form starts with a consonant / $g, h, k h, a, l, u, e$ dano /. 
The morphological process in the word affixation and reduplication in words with the addition of suffix to the reduplication of the word in the narrative essay of students. Adding prefixes to the word play chase, the addition of prefixes to the basic word of play changes morphologically and morphemically by preserving the phoneme / $\mathrm{r} /$ on the prefix playing. This happens not because the basic word does not occur with phoneme Bering because the basic word does not start from / $r$ / or the process of nasalization which is impinging and changing into another sound form.

In prefixes that make up on BMT so much that it should be noisy in BI, the word dumb in the sound / $r$ / is not sluggish or nasal. The sound / $\mathrm{r} /$ sound is strong because there is no change in shape and sound in the word gadoh. Affixation can occur due to the influence of regional languages and thus becomes the interference of Suwito's (1988: 66) morphological form. Morphological field references occur also from regional language affixes. Chaer (2003: 123) states as follows. The use of forms of crash, truancy, smallness, and expensiveness in the Indonesian language also includes cases of interference, because the affixes used there are from Javanese or Sudanese and the Jakarta dialect. The standard form is getting hit, stuck, too small, and too expensive.

Reduplication of the chase word with the addition of suffixes makes a base word that experiences reduplication with the addition of suffixes will shift to form a new syllable with the suffix, because the suffix is added to the basic form which ends with a consonant. Whereas the reduplication of the chase word with suffix is a repetition of the basic root words with full repetition of the suffixed form accompanied by basic word reduplication. Reduplication also occurs in the profit loop repetition, mutation is the reduplication of the syntax of repetition of the whole basic root, which is the repetition of the basic words completely without changing the reduplication with affixes. (Chaer, 2008: 181) repetition of the basic form, namely intact repetition of the basic form that is repeated without making changes to the physical shape of the root. Whereas the suffixed root repetition is done by adding the suffix at the end of each repetition and only adding the end to the last repetition.

\subsection{Free and Bonded Morphemes}

In narassi's essays students have free and bound morphemes in it. According to Chaer (2008: 17) free morpheme is a morpheme which without being related to other morphemes can be directly used in its short speech, the free morpheme is a basic morpheme. Whereas bound morphemes are morphemes which must first be given affixes or join with other morphemes. In the following table there are nine free morphemes that can be directly used in student writing without any additional affixation to stand in the sentence. And there are six bound morphemes that must get affixation and reduplication to stand in the sentence. See the following table 4.15 for free and bound morphemes in students' narrative essays.

Table 5. Free Morphemes and Bound Morphemes

\begin{tabular}{|l|l|l|l|l|}
\hline No & Free Morpheme & No & Bound Morpheme & Allomorph \\
\hline 1 & Jidat & 1 & Tertidur & Ter \\
\hline 2 & Kejar & 2 & Bermain & Ber \\
\hline 3 & Lece & 3 & Semalam & Se \\
\hline 4 & Umpet & 4 & Bergadoh & Ber \\
\hline 5 & Kubur & 5 & Terlentang & Ter \\
\hline 6 & Petang & 6 & Menjolok & Me \\
\hline
\end{tabular}




\begin{tabular}{|l|l|l|l|l|}
\hline 7 & Untung & & & \\
\hline 8 & Cabut & & & \\
\hline 9 & Gerak & & & \\
\hline
\end{tabular}

\section{Conclusion}

Morphological interference in the form of affixation can occur in the front, such as affixation, but also the phoneme sequencing of affixed morphemes in the nasal form on the prefix ber on the BMT which should not be sluggish or nasal in BI. Then, the morphological field of reference occurs also from the affixes of regional languages, the use of word root reduplication and the reduplication of root suffixes. In the narrative essay students have free and bound morphemes in it. Where free morpheme is a morpheme that can stand alone without relating to other morphemes that can be directly used in his speech / short writing of free morpheme in the form of a basic morpheme. While bound morphemes are morphemes that must first be given affixes or join with other morphemes. There are phonological equations, morphology in Malay and Indonesian. Because, Indonesian root groups adopted the Malay language as the basis for use. So that many lexical meanings are homonym, homograph and hyponym in Malay that are similar to Indonesian and other regional languages.

\section{References}

Amral, Sainil. 2011. Interferensi Leksikal Bahasa Melayu Jambi Dalam Penggunaan Bahasa Indonesia Lisan. Jurnal. Jambi: Universitas Batang Hari.

Armia, 2014. Interferensi bahasa Aceh terhadap Bahasa Indonesia. Jurnal Ilmiah Kebahasaan. Banda Aceh: Universitas Syiah Kuala.

Aslinda dan Syafyahya, Leni. 2007. Pengantar Sosiolinguistik. Refika Aditama: Bandung.

Bistok, Sirait, dkk. 1985. Pedoman Karang-Mengarang. Jakarta. Department of Education and Culture.

Chaer, A.2012. Linguistik Umum. Jakarta: PT Rineka Cipta.

------- 2009. Pengantar Semantik Bahasa Indonesia. Jakarta: PT Rineka Cipta

Chear, A dan Agustina. 2004. Sosiolinguistik (perkenalan awal). Jakarta: Rineka Cipta.

Fitriasari, Lintang. 2011. Interferensi Leksikal Bahasa Jawa Dalam Penggunaan Bahasa Indonesia Ragam Lisan Oleh Siswa TK Aba Perumnas Condongcatur. Thesis. Yogyakarta: Universitas Negeri Yogyakarta.

Gie, The Liang. 1995. Pengantar Dunia Karang-Mengarang. Yogyakarta. Liberty.

https://www.scribd.com/doc/288490101/Bahasa-Tacehamiang-Atau-Bahasa-Melayu

Tamiang.14 November 2017

https://www.kompasiana.com/bustamiaceh/selayang-pandang-tentang-etnik tamiang 54ffd2058133119068fa70ec. 14 November 2017

http://wealthy-village.utsmakassar.web.id/eng/2840-2725/LanguageTamiang 40429_utsmakassar_wealthy-village-utsmakassar.html. 14 November 2017

Keraf, Gorys. 2005. Argumentasi dan Narasi. Jakarta: Gramedia.

Kridalaksana, Harimurti. 1989. Pembentukan Kata Dalam Bahasa Indonesia. Jakarta: Gramedia. 
Mariyana, Lina. 2011. Interferensi Leksikal Bahasa Indonesia Dalam Bahasa Jawa Pada Teks Berita Pawartos Jawi Tengah Di Cakra Semarang TV. Skripsi. Semarang: Universitas Negeri Semarang.

Ramlan. 2001. Ilmu Bahasa Indonesia:Sintaksis. Yogyakarta.:Up Karyono

Rindu Marito, Fourmey. 2016. Interferensi Gramatikal Bahasa Batak Toba Pada Karangan Narasi Bahasa Indonesia Siswa SMA Negeri 1 Kecamatan Simanindo Kabupaten Samosir. Thesis. Medan: Universitas Negeri Medan.

Sugiono. 2013. Metode Penelitian Kuantitatif Kualitatif dan R\&D. Bandung: Alfabeta

Sukawati, Nyimas. 1999. Interferensi Morfologi Bahasa Karo Pada Terjemahan Ahasa Indonesia Suswa Kelas 1 SLTP Negeri 1 Tiga Panah Tahun Pembelajaran 1998/1999. Thesis. Medan: Universitas Negeri Medan

Sulaiman, Budiman dkk. 1993. Tata Bahasa Tamiang. Jakarta: Center for Language Development and Development of the Department of Education and CultureSupriatin,

Titin. 2014. Interferensi Bahasa Indonesia kedalam Abstrak Skripsi (Kajia Morfologis dan Leksikosemantis). Jurnal. Purwakarta: Universitas Purwakarta.

Suwito. 1985. Sosiolinguistik Pengantar Awal. Solo. Henary Offset.

Waridah, Ernawati. 2008. EYD \& seputan Kebahasa-Indonesiaan. Bandung: Kawan Pustaka.

Wahyuningsih, Indah. 2011. Interferensi Leksikal Bahasa Indonesia Dalam Bahasa Jawa Pada Jagad Jawa Harian Umum Solopos (Suatu Kajian Sosiolinguistik). Skripsi. Surakarta: Uiversitas Sebelas Maret

Wulan Dariani S, Annura. 2012. Intererensi Fonologi, Morfologi, Dan Leksikal Dalam Komunikasi Formal Mahasiswa Sastra Indonesia Fakultas Ilmu Budaya Universitas Airlangga. Jurnal. Surabaya: Universitas Airlangga.

Weinreich, U. 1968. Language in contact. Finding and problem. Paris: Mounton the hague 